\title{
The Improvement of Any School Process Is the Role of Teacher
}

\author{
Tabasum Rashid ${ }^{1}$, Mohd Shamim² and Ruhee Rashid ${ }^{3}$ \\ ${ }^{1}$ Lecturer in Education Govt.Higher Secondary School Yaripora Kulgam Kashmir ( $J$ \& K). \\ $J$ \& K Department of Education, 2 Department of Education Lovely Professional University Jalandhar \\ (Punjab), 3 Department of Education Kashmir University,Srinagar( $J \& K)$.
}

\begin{abstract}
At the heart of the success of any school improvement process is teachers' willingness to change and improve their knowledge, attitudes and practices. The role of school leadership is crutial in combining professional and accountability measures for effective collaboration of teachers in this regard. Using a case study design, the study explored the role of school leadership in mediating teacher appraisal for development. A purposive sample of two schools and nine participants were selected for the study. The study established that proactive leadership is key for any teacher appraisal system. The culture and professionalism created in school was found to be essential in creating an effective appraisal system. Furthermore, the existence of on-site and off-site professional development activities are were essential for appraisal system. Finally, the study found that any effective teacher appraisal system requires mediation between externally and internally initiated teacher development activities.
\end{abstract}

Key words: Teachers, School Improvement, Professional development, IQMS, Pressure and Support.

\section{Introduction:}

In 2004 the government introduced a new appraisal system called the Integrated Quality Management Systems (IQMS). Its inception brought not only confusion but also chaos in schools.Teachers are ill-prepared and incapable of curriculum delivery. This led to the erroneous conception that appraisal schemes are meant to intimidate and weed out incompetent teachers. This new IQMS program combined development appraisal (DA), performance measurement (PM) and whole school evaluation (WSE). These three were to inform and strengthen one another but their interaction became a challenge for many teachers. The aim of IQMS was to ensure quality education for all and meet one of the Millennium Development Goals of quality education. To meet this goal, teachers were to be empowered, motivated and trained. This necessarily required quality management that called for monitoring of teachers but also supporting teachers the in educative process. Building organisational capacity is key to any improvement process but inevitably involves people within the organization to absorb new ideas and ways which necessarily come with uncertainties (Fuhrman, 2002). School leadership thus have a task to manage and mediate the level of resistance to change and align staff towards a common vision in the midst of such turbulence. The success of any reform initiative depends to some extent on the strategic and dynamic nature of its leadership. The principal and other senior teachers determine the climate and the efficiency of staff. Hence, the degree to which school staff will accept teacher appraisal or the new IQMS program in school depends, to a greater extent, on the creativity and proactiveness of the school leadership. Thus, this study explored the role of school leadership in teacher appraisal for professional development with specific reference to the current IQMS program.

\section{Review of Related Literature:}

The review of related literature showed that there is a close relationship between teacher appraisal, teacher professional development and school improvement. Teacher appraisal identifies, through personal growth plans (PGP), individual teacher personal and professional needs as well as the developmental needs of the school. School and individual needs are collated and harnessed by the Staff Development Team (SDT) and integrated into the School Improvement Plan (SIP). Support opportunities are organised and designed to enhance teacher knowledge and practice that inevitably leads to increased student performance.

\section{Inside-out and Outside-in:}

The school effectiveness approach is standards-based or outside-in which means that there is an overemphasis on outcomes as it is performance related. Hence, it is externally initiated and administered, epitomised in the Fleisch (2001) EAZ schools in South Africa. Such programs start with a set of standards that are clear, parsimonious and rigorous (Taylor, 2002, p.4). On the other hand, Inside-out, programs are process-oriented, school based and often lead to or enhances school improvement. They are school-initiated; which means they are school-based. 


\section{Pressure and Support:}

Two main change tools are used in school improvement process: pressure (accountability) and support (capacity building). While there is agreement on the use of both, there is discord in their sequencing. Proponents of pressure as a tool for improving schools argue that schools must be functional before they can receive support (Fleisch 2001, Taylor 2002).

They opine that pressure lays the foundation for support. As teacher support has not been effectively utilized, teacher development must thus begin with accountability followed by support. For instance, as Taylor (2002) argued, accountability measures must always precede capacity building (support) measures. Fleisch and Taylor advocate external influence as a strategy to motivate teachers to achieve objectives and improve practice. Shalem and Elmore (2003) however differ from this position and argue that support must precede pressure in school improvement. Elmore (2000) concurs with this position argues that internal accountability should precede external accountability. In contrast, Shalem (2003) argues that teachers need empowerment to enable gain autonomy and take control of their own affairs. In this way, they would be committed since they will be viewed as policymakers and implementers or reformers. Therefore, a sequence and balance between pressure and support is healthy for school reform. Nevertheless, as Chinsamy (2002) observed schools in South Africa have not been given enough pressure to take responsibility for learners' performance.

The sequence and balance between pressure and support must be well managed given that pressure without support may perpetuate resistance and alienation while support without pressure may lead to drift and a waste of resources (Fullan,1995). For this reason, school leadership must appropriately and adequately align and mediate pressure and support for a well designed professional development system. Nevertheless, Taylor (2002) maintains that support must always precede pressure. Outside-in and inside-out programs employ different measures for improvement. While the accountability measures give direction, set performance standards and monitor outcomes, inside-out initiatives focus on support measures and empower teachers through capacity building, provide training and development appraisal. The DAS program is a support measure that aims at identifying individual teacher needs and the strategies to support them (Taylor 2002). An effective appraisal for development thus combines both inside-out and outside-in approaches. From the inside-out perspective, internally generated programs for development appear more effective than externally 'imposed' initiatives. They promote teacher involvement and commitment as teachers are empowered to participate in the improvement process.

\section{Teacher Professional Development:}

Formative appraisal is monitoring for the purpose of teacher professional development. Teachers need to continuously improve and upgrade their knowledge and skills and teacher appraisal does just that. For this reason teacher development should be an integral part of the school development plan. Nevertheless, appraisal for teacher development over the years has not been viewed positively by teachers. For instance, Reitzug (2002) views teacher appraisal as processes and activities designed to enhance the professional knowledge, skills, and attitudes of educators so that they might, in turn, improve student learning. Developing teacher knowledge and skills is not only acquiring existing knowledge and skills but also the ability for teachers to critically reflect on their practice and fashion new knowledge and beliefs about content and pedagogy. In order to change teaching practice in significant and worthwhile ways, teachers must not only learn new subject matter and new instructional techniques, they must be able to alter beliefs and conceptions of practice (Reitzug, 2002).

Leaders are characters who single-handedly pull and push organisational members forward by force of their personality,bureaucratic clout and political know-how. For that reason leaders must be decisive, forceful and visionary. Leaders must successfully influence events and people so that school vision becomes reality. Instructional leadership is, therefore, crucial and central to the success of school reforms. School based leadership is a function of both the principal as key change agents within the school. The principal's role is, therefore, pertinent to implementation of IQMS and other school improvement processes. The school principal must be proactive, creative and visionary. They should be able to articulate and communicate the vision of the school and direct the staff towards the achievement of goals of IQMS.

\section{Design and methodology:}

The study, located in the qualitative paradigm, recognises the capacity of human beings to interpret their social world. The study used the case design (McMillan \& Schumacher, 2001). This approach, nevertheless, had some limitations. Data collection and analysis was time consuming. Similarly, and as Bell (1993) has indicated, there is a danger of biasness and subjectivity in the final report. The area of study and the materials to report in the final report were both subjectively selected. There is thus a danger of distortion as it is difficult to cross-check with another researcher. A purposeful sample size of two schools was chosen for the study with nine participants: four teachers, one principal and four HoDs (McMillan et al., 2001: 175).

The schools are information- rich on the topic of teacher appraisal for development, hence the choice of sample.To respect confidentiality and anonymity, the schools are designated as school A and school B The data was obtained from teachers as well as members of the SMT. Three research tools were employedquestionnaires, interviews and observation. Tape-recorded interviews were transcribed and analysed. Through 
member checking interviewer biases were minimized. Questionnaires were rigorously scrutinised with the help of supervisors and this increased the reliability of the questionnaire. The use of three research instruments also maximised validity and reliability. For instance, the weakness of one instrument was enhanced by the strengths of the other.

\section{Presentation of Data:}

In both schools there was a sense of collaboration among staff. The relationship among staff and school leadership was positive. The study suggested that the principals endorsed good staff morale and motivated their staff. Teacher participants indicated that "school leadership did not take decisions without consulting them". According to one of the teachers, "all of us are involved in school decision making". This climate of collaboration promoted commitment and dialogue among the members of staff. This was reiterated by another teacher in school A who said, "the principal ensured that we work in teams and work across our grade levels and learning areas". This was aimed at building social trust and dialogue among staff members. This collaborative culture encouraged teachers to work together in a harmonious manner. The collaboration and team spirit further enhanced trust and commitment in teachers' responsibilities. Teachers were enthusiastic in both on-site and offsite programs in order to promote staff practice and improve student performance.

Professional development activities emanated from the SIP and through the liaison of the teachers' resource centre training courses and seminars were offered to teachers. Participants were appreciative of the IQMS since it was aimed at providing assistance to the developmental needs of teachers in the teaching and learning process. The IQMS, though externally initiated, involved everybody in its implementation. Hence, the program was embraced because of the trust and positive report among the teachers. However, the system was seen to be time consuming and also involved too much paperwork. For this reason it disrupted teachers' instructional responsibilities. This notwithstanding, teacher appraisal is a prelude for effective teacher development and student learning. In the same way an effective teacher development would depend on the amount of support activities provided and the follow-up of these activities. Through such support services the members of staff are encouraged and motivated to make the best use of in service programs when they are made available.

\section{Discussion:}

Effective leadership is a key component for school improvement. As Leithwood (1988) argues, "if students deserve a qualified teacher as an inalienable right, then logic leads one to the conclusion that teachers also deserve a highly qualified and creative principal as a right as well". That is if schools are to become learning organisations (Senge 1990), then school leaders must serve as catalyst for school reform. Schools that are learning organisations focused on improving teaching and learning practices. High performing schools demand principals who really understand the teaching and learning process (Harris, 2002). Effective or high performing schools promote collaborative culture and create favourable environments for teaching and learning. Principals in these schools promote teamwork and collaboration among the staff.

They are also both task and people oriented. They believe that people work better when they are happy in their jobs and work places. Teacher satisfaction which depends on trust, confidence and openness among staff is their key principle. School leaders believe that attitudes such as these promote empowerment, dialogue, and support among teachers. The principals in this research established these virtues by their constant encouragement and affirmations of the staff. In contrast, the principals that are task oriented cannot educe the support of teachers in school improvement. According to Fuhrman (2002:41) the effectiveness of teacher evaluation depends on the strength of the school's internal organisational capacity. The key to effectiveness in schools is thus shared commitment and collaboration among staff to achieve student learning. Fuhrman (1999) concurs and asserts that collaboration and team work promote professional dialogue and which is a determinant for achieving the IQMS. Showers and Joyce (1988) also contend that collegial relationships provide opportunities to teachers to develop new meanings, new behaviours, new skills and new beliefs about teaching and learning. They argue that, in meaningful collegial relationships, teachers seek to work with a colleague with whom they feel comfortable and who can provide constructive feedback for the purpose of appraisal for development.

The principals in the study were enthusiastic on improving teaching and learning through the various support services they gave to teachers to improve classroom practice. According to Darling-Hammond (1991), schools can improve, if teachers are supported in their growth as professionals. It is, therefore, the responsibility of principals and SMT to encourage and assist teachers to grow and develop in their profession. Schools must be structured to support quality teaching and transforming the schools into learning organisations (Harris, 2002). In both schools efforts were made to provide on-site and off-site professional development activities despite financial constraints. A teacher appraisal scheme for development must be seen as a professional activity (Darling-Hammond, 1989). Such an activity must be accepted by all teachers in continuous pursuit of improved 
practice. Hence, a teacher appraisal scheme is both a necessity and a professional responsibility for teachers. Thus, school principals must endeavour to relinquish control over the appraisal process and allow teachers to manage, own and control key aspects of the process (Darling-Hammond, 1989 \& Marshall, 2005). Effective professional activities depend on the attitude of the principal towards the staff. A positive and collaborative attitude and rapport promotes school improvement and enhanced student achievement. Teacher appraisal activities should be seen as developmental and school principals must nurture this attitude in the staff. They should also make efforts to develop and build a good sense of human relationships necessary to inculcate trust and confidence among the staff visà- vis the appraisal scheme.

\section{Conclusion:}

The study concludes that proactive instructional leadership is key to any appraisal for development. The culture andprofessionalism created and promoted in the school is essential for any effective appraisal scheme. Secondly, the commitment of the leadership in seeking out both on-site and off-site professional development activities for teachers is also central for any effective appraisal for development. Thirdly, the awareness of school leadership of the conditions necessary for successful teacher appraisal is a necessary pre-requisite for any appraisal for development. Furthermore, there is need for principals to mediate externally initiated teacher development activities to ensure that there is no conflict between internal and external appraisal activities. The two should be well managed and integrated for school effectiveness.

\section{References:}

[1] Bell, J., (1993). Doing Your Research Project: A Guide for First-Time Researchers in Education and Social Sciences. Buckingham: Open University Press.

[2] Chinsamy, B., (2002). Successful School Improvement and the Education District Office in South Africa: Some Emerging Propositions.

[3] Darling-Hammond, L., (1989). Accountability for Professional Practice. Teachers College Record, Vol. 91, No 1

[4] Darling-Hammond, L., (1989). Evaluation and the Teachin Profession. In: Evans A \& Tomlinson T (eds), Teacher Appraisal: A Nationwide Approach, Jessica Kingsley: London

[5] Darling-Hammond, L., (1991). Accountability Mechanisms in Big Urban City Schools. ERIC Clearinghouse on Urban Education 71, $1-8$

[6] Darling-Hammond, L., Wise, A. E. \& McLaughlin, M. W. (1985). Teacher Evaluation and Teacher Professionalism. Educational leadership, 42: 4: $28-33$.

[7] Elmore, R. (2000). Building a New Structure for School Leadership. New York: The Albert Shanker Institute

[8] Fleisch, B. (2001). Managing Educational Change: The State and School Reform in the New South Africa. Wits Manuscript

[9] Fuhrman, S. (1999). The New Accountability. CPRE Policy Brief, Philadelphia PA: University of Pennsylvania

[10] Fuhrman, S. (2002). Accountability and Professional Practice. ERIC Clearinghouse on Urban Education 90, 2 - 16

[11] Fullan, M. (1995). Successful School Improvement. Open University Press: Philadelphia.

[12] Fullan, M. (2003). Tri-Level Reform: The Role of the District. In: Fullan, M. (2003). Change Forces with a Vengeance: Routledge Palmer

[13] Harris, A., (2002). Democratic Leadership for School Improvement in Challenging Contexts. Institute of Education, University of Warwick

[14] Leithwood, K. A. (1988). The Principal's Role in Teacher Development. In Fullan, M. \& A. Hargreaves (eds.)

[15] Teacher Development and Educational Change. The Falmer Press: London.

[16] Marshall, K. (2005). It is Time To Rethink Teacher Supervision and Evaluation. Phi Delta Kappan, Bloomington, Vol. 86 (10), pg. 727

[17] McMillan, J. \& Schumacher, S. (2001). Research in Education: A Conceptual Introduction, London: New York. Reitzug, U. C., School Reform Proposals: The ResearchEvidence. University of North Carolina at Greensboro. [www.asu.edu/epsl/EPRU/epru_Research_Writing.htm]

[18] Garner, J. (1973). "The nature of teaching and effectiveness of teachers". In : Lomax DE (ed.) 1973, The Education of Teachers in Britain, Wiley, London, pp.425-36.

[19] Hough and Duncan (1970), "The Study of Teaching", New York; Holt, Rinehart and Winston, New York. Kumar (2005). "Teacher Effectiveness and job satisfaction of Women teachers". Edutracks, Vol.4, No.7, March 2005, pp.29-30.

[20] Kagathala, A.B. (2001). "A study of the effectiveness of teachers of secondary schools in Gujarat". Journal of Education and Psychology, Vol.LIX, No.4, (July - Dec.2001), pp.26-33.2, (October 2003), pp.17-27.

[21] Ryans, D.G., (1960). "Characteristics of teachers, their description, Comparison and appraisal". Washington, D.C. American Council of Education, p.1.

[22] Amsarani, S.R. (2002). "Teacher Effectiveness of Second Language teachers in higher secondary schools". Journal of Research in Education, 2002-2003, Vol.I, No.2, (Oct. 2002), p.21.

[23] Arora, K., (1978). "Differences between effective and ineffective teachers". New Delhi; S.Chand and Company, pp.31-38.

[24] Borich (1992). "Teacher effectiveness and concluded that key behaviours characterizing effective teachers". Indian Educational Review, Vol.XXIII, No.3, (April 1992), pp.103-114.

[25] Johnson, J.R, and Rusch, F.R. "Secondary Special Education and Transition Services". Carrier Development for Exceptional Individuals, 16, no. 1 (Spring 1993).

[26] LaBahn, J. (1995). Education and parental involvement in secondary schools problems, solutions, and effects. Educational Psychology interactive. Valdosta, GA: Valdosta State University. Available online: [http://chiron.valdosta .edu/whuitt/files/parinvol.html]

[27] O’Neill, J.; Gothelef, C.; Choen, S.; Lehman, L.; and Woolf, S.A. Curriculum Approach to support the Transition to Adulthood of Adolescents with visual or dual sensory impairments and Cognitive Disabilities. New York: Hunter College of the City University of New York, (1990).

[28] Shaver, A.V., \& Walls, R.T. (1998). Effect of title I Parent involvement on student reading and mathematics achievement. Journal of research and Development in Education, 31(2), 90-97. EJ561992.

[29] William jeynes (2004) parental involvement and secondary school student Educational Outcomes: A Meta-Analysis. Harvard family research project. Harvard school of Education. Volume X, Number 4, winter 2004/2005 issue Topic: Evaluating family Involvement programs promising practices. 